\title{
ANALISA PENGETAHUAN MASYARAKAT TENTANG PENGGUNAAN DISINFEKTAN TERHADAP SIKAP PENCEGAHAN PENYEBARAN COVID-19
}

\section{THE RELATIONSHIP BETWEEN COMMUNITY'S KNOWLEDGE LEVELS ABOUT THE USE OF DISINFECTANTS AND ATTITUDES TOWARDS COVID-19 SPREAD PREVENTION}

\author{
Eni Marlina Sofiana ${ }^{\bowtie}$, Cornelia Dede Yoshima Nekada, Tia Amestiasih \\ Program Studi Keperawatan Program Sarjana Fakultas IImu Kesehatan Universitas Respati Yogyakarta \\ Correspondence Email : enimarlinasofiana21@gmail.com
}

\begin{abstract}
ABSTRAK
Masyarakat merupakan salah satu elemen penting yang memiliki peran sebagai agen perubahan. Hadirnya masyarakat dalam bidang pencegahan penyebaran COVID-19 ini maka diharapkan dapat memiliki tingkat pengetahuan dan sikap pencegahan yang baik di suatu wilayah tersebut. Penelitian ini bertujuan untuk menganalisa pengetahuan masyarakat tentang penggunaan disinfektan terhadap sikap pencegahan penyebaran COVID-19 di Dusun 05 Tanjung Asri Braja Emas Way Jepara Lampung Timur. Metode yang digunakan yaitu kuantitatif, dengan desain penelitian cross sectional, pendekatan deskriptif analitik. Populasi sebanyak 87 responden. Instrumen menggunakan kuisioner dan dianalisis menggunakan uji Somers'D. Hasil ditunjukan pengetahuan responden tentang penggunaan disinfektan sebagian besar dalam kategori cukup. Sikap pencegahan penyebaran COVID-19 sebagian besar dalam kategori negatif. Hasil uji bivariat dengan $p$ value 0,010 yang artinya ada hubungan tingkat pengetahuan masyarakat tentang penggunaan disinfektan terhadap sikap pencegahan penyebaran COVID-19 didusun 05 Tanjung Asri Braja Emas Way Jepara Lampung Timur.
\end{abstract}

Kata kunci: pengetahuan;,sikap; desinfektan; pencegahan penyebaran covid-19

\begin{abstract}
Society is one important element that has a role as an agent of change. The presence of the community in the field of preventing the spread of COVID-19 is expected to have a good level of knowledge and prevention attitudes in an area. This study was aimed to analyze public knowledge about the use of disinfectants to prevent the spread of COVID-19 in Dusun 05 Tanjung Asri Braja Emas Way Jepara, East Lampung. The method used was quantitative, with a cross sectional research design, analytical descriptive approach. The population was 87 respondents. The instrument used a questionnaire and analyzed using the Somers'D test. The results show that the respondents' knowledge of the use of disinfectants is mostly in the sufficient category. Attitudes to prevent the spread of COVID-19 are mostly in the negative category. The results of the bivariate test with a $p$ value of 0.010 which means that there is a relationship between the level of public knowledge about the use of disinfectants to the attitude of preventing the spread of COVID-19 in the 05 Tanjung Asri Braja Emas Village, Way Jepara, East Lampung.
\end{abstract}

Keywords: knowledge; attitude; disinfectant; prevention of the spread of covid-19 


\section{PENDAHULUAN}

Corona virus Disease 2019 (COVID-19) yang disebabkan oleh SARS-CoV 2 berasal dari Wuhan China saat ini menyebar ke seluruh dunia. Pada awal Maret 2020 terkonfirmasi pertama kali kasus COVID-19 di Indonesia. WHO melaporkan pada tanggal 6 April 2020 COVID-19 menjadi pandemik global dan menginformasikan ke seluruh dunia untuk maksimal dalam membatasi penyebaran maupun jumlah positif kasus COVID-19. COVID-19 dapat menyebar melalui percikanpercikan dari bersin atau batuk penderita yang menempel pada benda lain seperti pakaian, alat-alat elektronik, dan benda yang ada disekitar orang dengan positif COVID-19. Guna melawan adanya peningkatan kasus COVID19 dilakukan tindakan preventif oleh pemerintah maupun masyarakat (Valerisha \& Putra, 2020).

Upaya Preventif sejauh ini merupakan kunci dalam penerapan pencegahan Covid-19 baik di masyarakat maupun penerapan di pelayanan kesehatan (Damanik dkk, 2021). Pencegahan penularan yang utama yaitu masyarakat wajib menggunakan masker saat berada diluar rumah, menutup mulut dan hidung saat bersin maupun batuk, mencuci tangan secara teratur dengan sabun atau Disinfeksi dengan kandungan alkohol minimal $70 \%$, menghindari kontak dengan orang yang terinfeksi, menjaga jarak, menahan diri dari menyentuh mata, mulut, hidung, dan area wajah. Penggunaan disinfektan untuk pencegahan COVID-19 salah satunya yaitu untuk membersihkan lingkungan rumah, pakaian, dan alat-alat elektronik (Valerisha \& Putra, 2020; Lestari 2020; Data Covid Lampung, 2020). Upaya lain telah dilakukan pula di berbagai daerah dalam mencegah

\section{METODE}

Jenis penelitian adalah kuantitatif dengan desain cross sectional dan pendekatan deskriptif analitik (Dharma, 2017). Penelitian ini dilaksanakan tanggal 28 Maret sampai tanggal 31 Maret 2021 di Dusun 05 Tanjung Asri, Desa Braja Emas, Way Jepara, Lampung Timur, penyebaran virus COVID-19 salah satunya adalah sosialisasi perilaku hidup bersih dan sehat (PHBS) pada anak usia dini di RA LabSchool IAIN Pekalongan (Tabi'in, 2020).

Disinfektan dibedakan menjadi 2 cara, yaitu fisika dan kimia, bahan kimia yang mengandung gugus- $\mathrm{COOH}$, golongan alkohol, yaitu senyawa kimia yang mengandung $-\mathrm{OH}$, golongan halogen atau senyawa terhalogenasi, yaitu senyawa kimia golongan halogen atau gugus- $x$. golongan fenol dan fenol terhalogenasi, golongan garam amonium kuartener, golongan pengoksidasi, dan golongan biguanid. Beberapa jenis Disinfektan terbukti efektif membunuh virus dan bakteri pada permukaan kayu, lantai, dinding, besi, kaca dan lingkungan sekitar (Simanjuntak, Silitonga \& Aryani, 2020). Namun, pada beberapa masyarakat ada yang belum mematuhi dan menerapkan penyemprotan.

Hasil wawancara kepada 15 responden remaja dan dewasa di Dusun 05 Tanjumg Asri Braja Emas Way Jepara Lampung Timur, 10 diantaranya menyatakan belum paham mengenai pengetahuan dan sikap pencegahan Covid-19 menggunakan Disinfektan untuk keperluan mencuci tangan, membersihkan lingkungan rumah, membersihkan lantai, membersihkan gagang pintu dan menggunakan disinfektan untuk membersihkan benda-benda elektronik. Masyarakat juga mengatakan belum paham kapan saja waktu yang tepat untuk menggunakan cairan anti kuman dan desinfektan. Berdasarkan fenomena tersebut penelitaian ini dilakukan untuk menganalisa pengetahuan masyarakat tentang penggunaan desinfektan terhadap sikap pencegahan penyebaran Covid-19.

Lampung. Teknik sampling purposive sampling didapatkan sampel sebanyak 87 responden. Variabel bebas dalam penelitian ini adalah pengetahuan masyarakat terhadap penggunaan disinfektan sedangkan variabel 
terikat adalah sikap pencegahan penyebaran COVID-19.

Analisa bivariat menggunakan uji Somers'D untuk mengetahui hubungan antara 2 variabel ordinal yang dibentuk dalam tabel kontingensi yang fungsinya sebagai tabel untuk menyatukan atau menyimpulkan frekuensi bersama dari observasi pada setiap kategori setiap variabel. Penelitian ini telah lolos uji etik dengan nomor surat 045.3/FIKES/PL/III/2021

\section{HASIL}

Hasil analisa karakteristik responden berdasarkan usia, jenis kelamin, pendidikan dan pekerjaan ditunjukan pada table 1 yaitu : usia responden mayoritas $(28,7 \%)$ pada usia 31 tahun - 40 tahun, 47 (54\%) responden berjenis kelamin perempuan. Pendidikan terakhir terbanyak adalah SMP dengan jumlah $31(35,6 \%)$ responden dan pekerjaan responden paling banyak adalah sebagai petani sejumlah $60(69 \%)$ responden.

Tabel 1.Karakteristik Responden berdasarkan usia, jenis kelamin, pendidikan dan pekerjaan $(n=87)$

\begin{tabular}{|c|c|c|c|}
\hline & Kategori & $F$ & $\%$ \\
\hline \multirow[t]{6}{*}{ Usia } & $<20$ Tahun & 4 & 4.6 \\
\hline & 20-30 Tahun & 22 & 25.3 \\
\hline & 31-40 Tahun & 25 & 28.7 \\
\hline & 41-50 Tahun & 23 & 26.4 \\
\hline & $>50$ Tahun & 13 & 14.9 \\
\hline & Total & 87 & 100.0 \\
\hline \multirow[t]{4}{*}{ Jenis Kelamin } & laki-laki & 40 & 46.0 \\
\hline & Perempuan & 47 & 54.0 \\
\hline & Total & 87 & 100.0 \\
\hline & SD & 28 & 32.2 \\
\hline \multirow[t]{5}{*}{ Pendidikan Terakhir } & SMP & 31 & 35.6 \\
\hline & SMA & 23 & 26.4 \\
\hline & Sarjana & 5 & 5.7 \\
\hline & Total & 87 & 100.0 \\
\hline & Petani & 60 & 69,0 \\
\hline \multirow[t]{4}{*}{ Pekerjaan } & Karyawan Swasta & 6 & 6,9 \\
\hline & Wiraswasrta & 7 & 8,0 \\
\hline & Tidak Berkerja & 14 & 16,1 \\
\hline & Total & 87 & 100.0 \\
\hline
\end{tabular}

Tabel 2 menunjukan distribusi tingkat pengetahuan responden tentang penggunaan disinfektan adalah dengan pengetahuan kategori baik sejumlah $24(27,6 \%)$ orang, pengetahuan kategori cukup sejumlah $55(63,2 \%)$ orang dan pengetahuan kategori kurang sejumlah $8(9,2 \%)$ orang.

Tabel 2. Distribusi tingkat Pengetahuan masyarakat tentang penggunaan disinfektan di Dusun 05 Tanjung Asri, Desa Braja Emas, Way Jepara, Lampung Timur, Bulan Maret 2021 ( $n=87)$

\begin{tabular}{lcc}
\hline Pengetahuan & $f$ & $\%$ \\
\hline Kurang & 8 & 9.2 \\
Cukup & 55 & 63.2 \\
Baik & 24 & 27.6 \\
\hline Total & 87 & 100.0 \\
\hline
\end{tabular}


Tabel 3 menyebutkan distribusi frekuensi sikap masyarakat dalam pencegahan penyebaran Covid-19 adalah masayarakat bersikap positip berjumlah 40 (46\%) orang dan masyarakat bersikap negative berjumlah 47 (54\%).

Tabel 3 Distribusi Sikap Pencegahan penyebaran COVID-19 Responden Di Dusun 05 Tanjung Asri, Desa Braja Emas, Way Jepara, Lampung Timur, Bulan Maret 2021 ( $n=87$ )

\begin{tabular}{lll}
\hline Sikap & F & $\%$ \\
\hline Negatif & 47 & 54.0 \\
Positif & 40 & 46.0 \\
\hline Total & 87 & 100.0 \\
\hline
\end{tabular}

Tabel 4 menyatakan bahwa ada hubungan tingkat pengetahuan masyarakat tentang penggunaan disinfektan terhadap sikap pencegahan penyebaran COVID-19 di Dusun 05 Tanjung Asri, Desa Braja Emas, Kecamatan Way Jepara, Kabupaten Lampung Timur, dengan nilai $p=0,010<0,05$

Tabel 4. Hubungan Tingkat Pengetahuan Masyarakat Tentang Penggunaan Disinfektan Terhadap Sikap Pencegahan Penyebaran COVID-19 di Dusun 05 Tanjung Asri, Desa Braja Emas, Kecamatan Way Jepara, Kabupaten Lampung Timur

\begin{tabular}{|c|c|c|c|c|c|c|c|}
\hline \multirow{3}{*}{ Pengetahuan } & \multicolumn{6}{|c|}{ Sikap } & \multirow[t]{3}{*}{$P$} \\
\hline & \multicolumn{2}{|c|}{ Negatif } & \multicolumn{2}{|c|}{ Positif } & \multicolumn{2}{|c|}{ Total } & \\
\hline & $f$ & $\%$ & $\mathrm{~F}$ & $\%$ & $f$ & $\%$ & \\
\hline Kurang & 7 & 8,0 & 1 & 1,1 & 8 & 9,2 & \\
\hline Cukup & 31 & 35,6 & 24 & 27,6 & 55 & 63,2 & 0,010 \\
\hline Baik & 9 & 10,3 & 15 & 17,2 & 24 & 27,6 & \\
\hline Total & 47 & 54,0 & 40 & 46,0 & 87 & 100,0 & \\
\hline
\end{tabular}

Uji somers'D.

\section{PEMBAHASAN}

Tingkat pendidikan responden dapat sangat berpengaruh terhadap tingkat pengetahuan responden berdasarkan tingkat pendidikan terakhir responden. Ditunjukan bahwa karakteristik responden pendidikan terakhir responden yang dikatakan cukup adalah responden berpendidikan terakhir SMP 18 responden, responden berpendidikan terakhir SMA 14 responden, responden berpendidikan terakhir SD 19 responden dan responden berpendidikan terakhir sarjana sebanyak 4 responden dengan total seluruh responden 55 responden $(63,2 \%)$ dari total seluruh 87 responden (100,0\%). Penelitian yang dilakukan oleh Mujiburahman (2020) didapati bahwa semakin baik pengetahuan diakibatkan oleh karena daya tangkap dan pola pikir yang semakin berkembang dengan diiringi oleh bertambahnya usia seseorang.

Berdasarkan hasil penelitian bahwa karakteristik responden berdasarkan tingkat pengetahuan yaitu mayoritas responden termasuk memiliki pengetahuan dalam kategori cukup yaitu sebanyak 55 responden $(63,2 \%)$. Oleh karena itu, pengetahuan masyarakat tentang COVID-19 merupakan aspek yang sangat penting dalam masa pandemik seperti saat ini. Seseorang yang mempunyai pengetahuan yang baik terkait penggunaan disinfektan maka ada kecenderungan untuk berperilaku yang baik pula (Helena, 2021). Tingkat pengetahuan dipengaruhi oleh beberapa faktor diantaranya adalah umur responden. Wawan \& Dewi (2010) 
menyebutkan bahwa semakin cukup umur, maka tingkat kematangan dan kekuatan seseorang akan lebih matang dalam berfikir dan berkerja. Faktor lain yang menyebabkan tingkat pengetahuan cukup adalah tingkat pendidikan responden.

Penelitian yang dilakukan oleh (Suwaryo \& Yuwono, 2017), menyebutkan bahwa individu yang pernah menempuh jenjang pendidikan dengan derajat lebih tinggi maka akan memiliki pengalaman dan wawasan lebih luas, yang akan berdampak pada kognitifnya. Helena (2021) juga mengatakan dalam penelitiannya mengenai analisis faktor yang berhubungan dengan penggunaan disinfektan telah memiliki pengetahuan yang baik namun pada kenyataannya pengetahuan yang baik tidak menjamin bahwa tenaga kesehatan dan nonkesehatan akan memiliki perilaku pencegahan infeksi yang baik juga saat mereka bekerja di Puskesmas selama pandemic COVID-19. Masyarakat juga telah banyak menerima informasi dari berbagai sumber informasi baik cetak maupun non cetak

Berdasarkan hasil penelitian sebagian besar responden adalah termasuk memiliki sikap pencegahan penyebaran COVID-19 dalam kategori negatif yaitu sebanyak 47 responden $(54,0 \%)$, hasil ini menunjukkan bahwa tidak semua masyarakat menggunakan desinfektan sebagai upaya pencegahan penyebaran COVID-19. Sikap yang baik dapat menjadi upaya pencegahan terhadap penularan COVID-19 (Audria, 2019). Bentuk perilaku yang ditunjukkan antara lain kepatuhan dalam menggunakan masker saat berada di luar rumah, mencuci tangan dengan sabun atau hand sanitizer secara sering, menghindari kerumunan dan menjaga social ataupun physical distancing.
Cuci tangan adalah salah satu cara yang efektif untuk membunuh kuman, diketahui virus COVID-19 dapat menempel pada bagian tubuh terutama tangan yang menyentuh benda yang sudah tertular oleh droplet. Disampaikan oleh Kementerian Kesehatan bahwa $75 \%$ penularan virus covid adalah melalui percikan air ludah pada benda (Kemenkes, 2021). Oleh karena itu dalam penelitian ini, sebagaian responden melakukan cuci tangan setelah memegang benda yang telah disentuh sesuai dengan protokol kesehatan. Penelitian ini sejalan dengan yang dilakukan oleh Valerisha \& Putra (2020) menunjukkan bahwa bentuk perilaku yang ditunjukkan antara lain kepatuhan dalam menjaga jarak saat di luar rumah, selalu mencuci tangan dengan sabun atau hand sanitizer sebelum masuk rumah, toko/minimarket, atm dan fasilitas lainnya, taat menggunakan masker saat berpergian dan tidak bersentuhan atau salaman dengan orang lain.

Seseorang yang telah mengetahui tentang suatu informasi tertentu, maka dia akan mampu menentukan dan mengambil keputusan bagaimana dia harus menghadapinya. Dengan kata lain, saat seseorang mempunyai informasi tentang COVID-19, maka ia akan mampu untuk menentukan bagaimana dirinya harus berperilaku terhadap COVID-19 tersebut. Sikap pencegahan yang dilakukan berdasarkan pendidikan terakhir, pekerjaan dan umur mendapatkan hasil negatif dikarenakan dikarenakan hasil re rata dari perhitungan yang dilakukan yaitu hasilnya negatif. Masyarakat sesungguhnya dapat secara gotong royong untuk mengendalikan penyebaran Covid-19 ini dengan pemanfaatan desinfektan, seperti melakukan penyemprotan ke rumah-rumah 
warga secara rutin untuk meminimalkan penyebaran COVID-19.

Hasil penelitian menyebutkan hasil ada hubungan tingkat pengetahuan masyarakat tentang penggunaan disinfektan terhadap sikap pencegahan penyebaran COVID-19 di Dusun 05 Tanjung Asri, Desa Braja Emas, Kecamatan Way Jepara, Kabupaten Lampung Timur, dengan nilai significancy pada hasil menunjukan $(p=0,010<0,05)$. Pengetahuan tentang disinfektan memegang peranan penting dalam penentuan perilaku yang utuh karena pengetahuan akan membentuk kepercayaan yang selanjutnya dalam mempersepsikan kenyataan, memberikan dasar bagi pengambilan keputusan dan menentukan perilaku terhadap objek tertentu sehingga akan mempengaruhi seseorang dalam berperilaku dalam mencegah COVID-19.

Pengetahuan tentang disinfektan sangat menentukan setiap individu sehingga akan mempengaruhi sikap pencegahan COVID-19 dalam kehidupan sehari-hari. Karena semakin tinggi tingkat pengetahuan seseorang maka semakin mudah untuk menentukan apa yang harus pilih dan apa yang harus lakukan dalam kehidupannya sehari-hari. Pengetahuan merupakan salah satu faktor predisposisi yang mempermudah terjadinya perilaku seseorang (Notoatmodjo, 201). Teori ini menjelaskan bahwa pengetahuan adalah domain yang sangat penting untuk membentuk tindakan atau perilaku seseorang (Wawan \& Dewi, 2010). Perilaku yang didasari pengetahuan akan lebih langgeng dibanding dengan perilaku yang tidak didasari pengetahuan.

Sejalan dengan penelitian Suwaryo \& Yuwono (2017), bahwa pengetahuan memiliki kaitan yang erat dengan keputusan yang akan diambilnya, karena dengan pengetahuan seseorang memiliki landasan untuk menentukan pilihan. Selain itu, tingkat pengetahuan yang tinggi ini juga didukung dengan tingkat pendidikan. Tingkat pendidikan seseorang yang tinggi akan semkin mudah untuk mendapatkan akses informasi tentang suatu permasalahan pencegahan COVID-19. Bila membandingkan dari hasil penelitian antara jumlah responden yang memiliki pengetahuan yang cukup dan pengetahuan baik, terlihat bahwa responden yang memiliki pengetahuan yang cukup lebih banyak yang memiliki sikap yang negatif, sedangkan responden yang memiliki pengetahuan yang baik lebih banyak memiliki sikap yang positif. Hal ini menunjukkan pengetahuan memiliki peran penting untuk menentukan sikap individu, pengetahuan yang menyeluruh akan menentukan individu tersebut dalam bersikap. Masyarakat yang memiliki pengetahuan dengan baik tentang manfaat penggunaan desinfektan untuk pencegahan, ternyata dapat bersikap positif atau baik untuk menggunakan desinfektan sebagai salah satu cara mencegah penyebaran COVID-19.

\section{KESIMPULAN}

Rentang Usia Responden paling banyak adalah di usia 31-40 tahun, jenis kelamin paling banyak perempuan, pendidikan terakhir paling banyak SMP, pekerjaan paling banyak petani, sedangkan untuk tingkat pengetahuan paling banyak pada kategori cukup dan kategori sikap paling banyak adalah negatif. Hasil Analisa bivariat terdapat hubungan antara pengetahuan masyarakat tentang penggunaan disinfektan terhadap sikap pencegahan penyebaran COVID-19 di Dusun 05 Tanjumg Asri Braja Emas Way Jepara Lampung Timur. 


\section{REFERENSI}

A.Wawan, \& Dewi .M. (2010). Teori \& Pengukuran Pengetahuan, Sikap, Dan Perilaku. Nuha Medika.

Damanik RK., Gulo A. R. B., Simanjuntak. (2021). Upaya Pencegahan Penularan Covid-19 Melalui Sosialisasi Dan Penyemprotan Rumah Ibadah. Jurnal Kreativitas Pengabdian Kepada Masyarakat (PKM), P-ISSN: 2615-0921 E-ISSN: 2622-6030 Volume 4 No. 2 Tahun 2021. Hal 425433

Data Covid Lampung. (2020). Data Covid Lampung. Https://Www.Antaranews.Com/Berita/1737213/Di nkes-Lampung-Tempat-Tidur-Pasien-COVID-19Masih-Tersedia-262

Dharma, K. K. (2017). Metodologi Penelitian Keperawatan (Revisi Tah). CV. Trans Info Media.

Helena, K. F.P. (2021). Hubungan Antara Pengetahuan Dan Sikap Pencegahan COVID-19 Dengan Prilaku Pencegahan Infeksi Saat Berkerja Pada Tenaga Kesehatan Dan Non-Kesehatan Di Puskesmas Di Zona Merah Di Kota Medan Dan Kota Batam Selama Pandemi COOVID-19. Fakultas Kedokteran, Universitas Sumatra Utara.

Iqbal, M., Triyandi, R., Fitra, M., Sayoeti, W., Aulia, D.,.(2020). Kedokteran, F., \& Lampung, U. (N.D.).

Peningkatan Kognitif , Afektif Dan Psikomotor Melalui Promosi Kesehatan Tentang Bijak Menggunakan

Tabi'in, A. )2020). Perilaku Hidup Bersih dan Sehat (PHBS) pada Anak Usia Dini sebagai Upaya Pencegahan COVID-19. Jurnal Edukasi AUD. Vol 6 (1). 58-73 pp.
Antibiotik Pada Masyarakat Di Desa Umbul Natar Kelurahan Jatimulyo Kecamatan Jati Agung Lampung Selatan. 35-39.

Kementrian Kesehatan Indonesia. (2020). Jurnal Keperawatan Terpadu. Poltekes Mataram Jurusan Keperawatan. Jurnal Keperawatan. Vol 2. No (2). Http://Jkt.PoltekesMataram.Ac.Id/Index.Php/Home/Index.

Lestari. (2020). Hubungan Antara Prilaku Hidup Sehat (PHBS) Dengan Usaha Sekolah (UKS) Pada Siswa SMA Negreri Di Kota Surabaya.

Mujiburrahman, Riyadi, Ningsih. (2020). Hubungan Pengetahuan dengan Perilaku Pencegahan Covid-19 di Masyarakat. Jurnal Keperawatan Terpadu. Vol. 2, No. 2, https://doi.org/10.32807/jkt.v2i2.85

Notoatmodjo, Soekidjo. (2012). Metodologi Penelitian Kesehatan. PT. Rineka Cipta.

Simanjuntak, E. Y. B., Silitonga, E., \& Aryani, N. (2020). Jurnal Adisas. Jurnal Adisas, 1(3), 119-124.

Suwaryo, P.A.W \& Yuwono, P. (2017). Faktor-Faktor Yang Mempengaruhi Tingkat Pengetahuan Masyarakat Dalam Mitigasi Bencana Tanah Longsor.Program Studi Keperawatan. Stikes Muhamadiyah

Valerisha, A., \& Putra, M. Adi. (2020). Pandemi Global COVID-19 Dan Problematika Negara-Bangsa: Transparasi Data Sebagai Vaksin Socio-Digital. 